\title{
PELAKSANAAN KEBEBASAN BERAGAMA DI INDONESIA (EXTERNAL FREEDOM) DIHUBUNGKAN IJ IN PEMBANGUNAN RUMAH IBADAH
}

\author{
Nella Sumika Putri \\ Fakultas Hukum Universitas Padjadjaran \\ E-mail: nellasumikaputri@yahoo.com
}

\begin{abstract}
Recently, Indonesia faced issues about freedom of religion, in particular for construction the house of worship. It is part of freedom of worship which is element from freedom of religion and it should protected by State. eventhough State in implementation those right can make some limitation. J oint Decree 2006 is a form of restriction provided by the State to maintain public order. The implementation of freedom of religion is highly depend on the tolerance among religious community, particularly in the scope of forum externum. Cooperation beetwen all parties, i.e State as policy makers and implementers, religious leaders as a role model for the followers and society plays an important role in maintaining inter-religious harmony.
\end{abstract}

Keywords: human rights, freedom of religion, construction the house of worship

\begin{abstract}
Abstrak
Permasalahan kebebasan beragama akhir-akhir ini sedang menghinggapi masyarakat Indonesia, khususnya tentang pembangunan rumah ibadah. Pembangunan rumah ibadah adalah bagian dari kebebasan untuk beribadah yang merupakan bagian dari hak kebebasan beragama dan wajib dilindungi oleh negara, meskipun negara dalam melakukan perlindungan dapat melakukan pembatasan. SKB 2 Menteri tahun 2006 adalah bentuk pembatasan yang diberikan oleh negara dengan tujuan untuk menjaga ketertiban umum. Pelaksanaan kebebasan beragama sangat tergantung pada toleransi antara umat beragama khususnya dalam lingkup forum externum. Kerjasama antara semua pihak yaitu negara sebagai pembuat kebijakan dan pelaksana, pemuka agama selaku teladan bagi umatnya, dan masyarakat berperan penting dalam menjaga keharmonisan antar umat beragama.
\end{abstract}

Kata kunci: hak asasi manusia, kebebasan beragama, pembangunan rumah ibadah.

\section{Pendahuluan}

Indonesia merupakan suatu negara yang memiliki keberagaman baik dari suku, bahasa maupun agama. Keberagaman ini telah disadari oleh para pendiri negara kita sehingga melahirkan suatu semboyan yaitu Bhineka Tunggal Ika yang dapat diartikan sebagai berbeda-beda akan tetapi tetap satu. Hal tersebut merupakan konsep yang telah ada bahkan sebelum Indonesia merdeka. Prinsip Bhineka Tunggal Ika dimaksudkan agar semua komponen negara dapat menyadari bahwa keberagaman yang ada dapat menimbulkan suatu dampak baik positip mau pun negatif. Secara positip keberagaman merupakan suatu kekuatan yang apabila dapat digunakan dengan baik merupakan suatu potensi bagi kemajuan negara akan tetapi bila kebera- gaman tersebut mengakibatkan suatu perpecahan dan kebencian maka keberagaman ini menjadi suatu kekuatan negatif yang dapat menghancurkan bangsa Indonesia.

Apabila kita mengacu pada dasar negara sila pertama Pancasila dan pasal 29 konsitusi yaitu UUD 1945, Indonesia dapat dipandang sebagai negara yang "monotheist" karena pernyataan bahwa negara berdasarkan atas Ketuhanan Yang Maha Esa dapat ditafsirkan demikian. Atas dasar inilah, Indonesia tidak dapat dikategorikan sebagai negara agama karena dalam konstitusi tidak dinyatakan bahwa negara didasarkan atas suatu agama tertentu, tetapi Indonesia juga bukan merupakan negara sekuler yang memperhatikan permasalahan agama dan menyerahkan masalah agama pada perorangan 
dan masyarakat. ${ }^{1}$ Meskipun begitu dalam praktiknya, Indonesia hanya mengakui keberadaan enam agama yang dikenal sebagai agama "resmi" yaitu Islam, Protestan, Katolik, Hindu, Budha dan Konghucu, ${ }^{2}$ serta satu aliran kepercayaan terhadap Tuhan Yang Maha Esa. Keenam agama tersebut berada di bawah Departemen Agama, sedangkan diluar enam agama tersebut pembinaan berada dibawah Departemen Pariwisata. Agama-agama dan kepercayaan-kepercayaan asli nusantara juga tidak dimaksukkan ke dalam kategori agama. ${ }^{3}$

Sampai dengan Tahun 2000 berdasarkan sensus penduduk diketahui bahwa sebagian besar masyarakat Indonesia adalah Muslim yaitu sebanyak $88 \%$ sedangkan sisanya adalah Protestant, Katolik, Hindu dan kurang dari $1 \%$ penduduk Indonesia adalah penganut Budha, Yahudi dan agama-agama tradisional lainnya. ${ }^{4}$ $J$ ika dilihat dari kuantitas penganut agama maka akan terlihat adanya agama yang tergolong dalam kelompok mayoritas dan agama-agama yang termasuk dalam kelompok minoritas.

Perbedaan yang cukup signifikan antara golongan mayoritas dan minoritas ini menimbulkan berbagai permasalahan yang dapat mengakibatkan pelanggaran kebebasan beragama. Salah satu permasalahan yang terjadi di Indonesia akhir-akhir ini adalah masalah ijin pembangunan rumah ibadah. Permasalahan tentang pembangunan rumah ibadah merupakan salah satu motif dari berbagai tindakan anarkis yang dilakukan atas dasar agama yang mengatas namakan kuantitas dari penganut agama tertentu. Agama-agama yang tergolong minoritas seperti Protestan, Katolik maupun Hindu seringkali mendapatkan hambatan untuk menjalankan dan melaksanakan ibadah mereka, diantaranya

\footnotetext{
Sigit Ardianto, 2009, From Secularism into Modifed Pluralism: Comprehensive Application of J ohn Rawls's Justice as Fairness Theory in Defining State and Religion Relationship, Cornell law Library

2 Konghucu baru diakui sebagai agama resmi pada tahun 2006, pada masa kepemimpinan Presiden Abdurrahman Wahid.

3 Zakiyuddin Baidhawi, 2005, Kredo Kebebasan Beragama, Jakarta: PSAP Muhammadiyah, hlm xxiii.

4 http:// www. state. gov/ g/ drl/ rls/ irf/ 2009/ 127271.htm diakses tanggal 12 J anuari 2011
}

adanya suatu ketentuan tentang pembangunan rumah ibadah.

"Setara" mengindikasikan selama tahun 2009 saja terdapat lebih dari 200 pelanggaran terhadap kebebasan menjalankan ibadah. Jika difokuskan pada pelanggaran yang terkait dengan pembangunan rumah ibadah terjadi peningkatan yang cukup signifikan dari 2008 sebanyak 17 pelanggaran kemudian meningkat menjadi 18 pelanggaran pada tahun 2009 dan menjadi 28 pelanggaran sampai dengan pertengahan $2010 .{ }^{5}$ Pada pertengahan 2010 beberapa kejadian yang cukup menimbulkan konflik antar umat beragama antara lain peristiwa penyerangan penganut HKBP Ciketing Bekasi, J awa Barat, penyegelan Gereja HKBP Fialdelfia di Desa J ejalen, Tambun Utara, Kabupaten Bekasi oleh Pemerintah Daerah Bekasi, penyegelan gereja Blok I No. 7-8 Perumahan Sepatan Residen Desa Pisangan J aya, Kec. Sepatan Kabupaten Tangerang dan Iain-lain. Untuk tahun 2011 saja telah terjadi beberapa kasus yang diantaranya adalah terjadinya suatu aksi anarkis yang mengakibatkan terbunuhnya penganut Ahmadiyah di Pandeglang J awa Barat dikarenakan serangan dan kelompok tertentu, dan hal ini juga terkait dengan pembangunan rumah ibadah dan pelaksanaan kegiatan beribadah. Di awal Februari 2011, 500 siswa dari Pondok Pesantren Sinarmiskin, Kecamatan Bojongloa Kidul melakukan demonstrasi (damai) dalam rangka penolakan pembangunan gereja di lingkungan sekitar sekolah mereka. ${ }^{6}$

Apabila dilihat dari korban yang menjadi objek dari pelanggaran kebebasan beragama dalam hal ini tentang pembangunan rumah ibadah pada umumnya adalah kaum minoritas, kaum minoritas ini seringkali didiskriminasikan dan mendapat penyerangan oleh kelompokkelompok lain seperti FPI dan Hizbut Thahir dan bahkan ada yang dilakukan dengan bantuan dari pemerintah itu sendiri. Penganut Ahmadiyah,

http: / / www. wahidinstitute.org/ Program/ Detail/ ?id= 437/ hl=id/ Memotret Pelanggaran Kebebasan Beragam a Di Wilayah Rawan, diakses tanggal 28 J anuari 2011.

6 Detik. 2011. Áksi menolak pembangunan rumah ibadah, http: / / bandung. detik. com/ readfoto/ 2011/ 02/ 01/ 2004 49/1558505/501/1/, diakses pada 2 Februari 2011 
Syi'ah and al Qiyadah al Islamiyah mendapatkan perlakuan diskriminasi dan penyerangan dari kelompok-kelompok massa yang mengatasnamakan Islam.

Berbagai konflik dan kekerasan yang berlatar belakang agama menunjukkan bahwa Indonesia masih belum dapat menjalankan dan memberikan perlindungan terhadap hak asasi manusia khususnya tentang kebebasan beragama dalam hal ini terkait dengan hak warga negara untuk mendirikan rumah ibadah. Perlindungan terhadap kebebasan beragama pada dasarnya telah dinyatakan dan diatur secara jelas dalam pasal 28 dan 29 UUD 1945 serta dipertegas melalui UU No 39 tahun 1999 tentang Hak Asasi Manusia dan melalui peratifikasian berbagai konvensi internasional antara lain ICCPR. Berbagai pembatasan dan pelanggaran termasuk penyegelan, pembakaran, penyerangan atas nama agama adalah pelanggaran hak asasi manusia seperti yang terdapat dalam Pasal 18 ayat (3) International Covenant On Civil And Political Rights. Khususnya terkait dengan pembangunan rumah ibadah yang merupakan manifestasi dari pelaksanaan kepercayaan dari penganut suatu agama.

Berdasarkan uraian di atas, artikel ini dimaksudkan untuk menjelaskan tentang pengaturan ijin pembangunan rumah ibadah tidak bertentangan dengan hak kebebasan beragama dan upaya yang harus dilakukan sehingga pembangunan rumah ibadah di Indonesia tidak menjadi dasar timbulnya konflik di kemudian hari.

\section{Pengertian Agama}

Sangat banyak definisi yang dapat disampaikan tentang pengertian dari agama antara lain pengertian agama menurut Australia High Court yaitu complex of beliefs and practices which point to a set of values and an understanding of the meaning of existence. ${ }^{7}$ PBB sendiri menyatakan bahwa agama adalah suatu atribut pribadi yang sama dengan ras, etnis dan jenis kelamin. Hal ini dipandang sebagai feno-

\footnotetext{
Rebbeca Wilson dan Marry R Power, 2004, Conflict Resolution Styles among Australian Christian and Moslem, Bond University: Humanity and Social Science Papers, hlm 60
}

mena alami yang dapat menyebabkan suatu diskriminasi yang mengakuinya sebagai hak dan kebebasan. ${ }^{8}$ Definisi lain tentang agama adalah berdasarkan putusan pengadilan Amerika antara Davis v Beason, 133 U.S.,333, 342, $10 \mathrm{S.Ct}$ 229, 33 L.Ed. $637(1890)^{9}$ yang mendefinisikan agama sebagai:

"to one's views of his relations to his Creator, and to the obligations they impose of reverences for his being and character, and of obedience to his will". (pandangan seseorang atas hubungan dirinya dengan penciptanya dan kewajiban untuk menghormati karakternya dan menjalankan perintahnya)

Definisi lain tentang agama adalah didapat dari United States v Seeger, 380 U.S. 163, 165-66, 85 S.Ct.850, 13 L.Ed.2d $733(1965)^{10}$ menyatakan bahwa "agama" adalah:

"whether a given beliefe that is sincere and meaningful occupies a place in the life of its possessor parallel to that filled by the orthodox belief in God of one who clearly qualifies for the exemption. Where such beliefs have parallel positions in the lives of their respective holders we cannot say that one "is in relation to Supreme being' and the other is not" (kepercayaan yang diberikan secara tulus dan bermakna didalam kehidupan pararel dari pemeluknya atas kepercayaan terhadap Tuhan secara ortodox yang dilakukan untuk mendapatkan kebebasan. Yang mana keyakinan tersebut sejajar dalam setiap pemeluknya sehingga dapat dikatakan bahwa tidak ada yang lebih tinggi dibandingkan yang lainnya)

Deklarasi 1981 tentang Penghapusan Segala Bentuk Intoleransi dan Diskriminasi atas Dasar Agama atau Kepercayan mendefinisikan agama termasuk didalamnya adalah kepercayaan yaitu keyakinan non agama, misalnya ateis-

\footnotetext{
8 Brice Dickson "The United Nations and Freedom of Religion", The International and Comparative Law Quarterly, , 44 (2) April, 1995, hlm 327-357, Cambridge University Press on behalf of the British Institute of International andComparative LawStable URL: http:// www.jstor.org/ stable/ 760754 diakses pada: 25/ 08/ 2010 03:42

9 Frank S Ravitch, 2008, Law And Religion A Reader: Cases, Concepts, And Theory, American Case Book Series, Second Edition, hlm 580

10 lbid
} 
me, agnotisme dan kepercayaan lain asalkan kepercayaan tersebut berhubungan dengan agama. Berdasarkan berbagai definisi tentang agama di atas, pada dasarnya tidak ada suatu batasan tentang agama itu sendiri sepanjang itu merupakan keyakinan yang terdapat dalam diri seseorang dalam hubungannya dengan Tuhan. J adi berdasarkan hal ini tidak ada pembatasan apa yang disebut dengan agama sepanjang dia memiliki kepercayaan dan hubungan dengan Tuhan (atau bukan) maka dapat dikategorikan sebagai agama.

\section{Kebebasan Beragama}

Semua agama berdasarkan konstitusi memiliki hak untuk menikmati segala bentuk hak asasi untuk bebas dari segala bentuk diskriminasi atas dasar agama, memiliki perlindungan hukum yang sama dan perlakuan yang sama berdasarkan undang-undang dan untuk bebas dari diskriminasi dalam memperoleh perlindungan hukum. ${ }^{11}$ Perlindungan terhadap kebebasan beragama di Indonesia telah diatur secara tegas dalam konstitusi yaitu Pasal 29 UUD 1945 menyatakan, "Negara menjamin kemerdekaan tiap-tiap penduduk untuk memeluk agamanya masing-masing dan untuk beribadat menurut agama dan kepercayaannya itu." Hal ini juga sesuai dengan ketentuan Pasal $28 \mathrm{E}$ UUD Negara RI 1945:

1) Setiap orang bebas memeluk agama dan beribadat menurut agamanya, memilih pendidikan dan pengajaran, memilih pekerjaan, memilih kewarga-negaraan, memilih tempat tinggal diwilayah negara dan meninggalkannya, serta berhak kembali.

2) Setiap orang berhak atas atas kebebasan meyakini kepercayaan, menyatakan pikiran dan sikap, sesuai dengan hati nuraninya.

Kebebasan beragama adalah hak yang diakui dalam hukum internasional dan di semua sistem hak asasi manusia yang ada di dunia. Indonesia juga telah meratifikasi ketentuan in-

11 Louis Henkin, "Religion, Religions, and Human Rights", The J ournal of Religious Ethics, 26 (2) Fall, 1998, hlm. 229-239, J ournal of Religious Ethics, Inc Stable URL: http:// www.jstor.org/ stable/ 40008655 diakses pada: 25/08/2010 05:12 ternasional yang terkait dengan perlindungan kebebasan beragama melalui UU No 12 tahun 2005 tentang peratifikasian ICCPR. Pasal 18 ayat (1) Kovenan Hak-hak Sipil dan Politik menyebutkan bahwa, "Setiap orang berhak atas kebebasan berpikir, keyakinan dan beragama. Hak ini mencakup kebebasan untuk menetapkan agama atau kepercayaan atas pilihannya sendiri, dan kebebasan, baik secara sendiri maupun bersama-sama dengan orang lain, baik di tempat umum atau tertutup, untuk menjalankan agama dan kepercayaannya dalam kegiatan ibadah, pentaatan, pengamalan, dan pengajaran".

Deklarasi tentang Penghapusan Semua Bentuk Intoleransi dan Diskriminasi Berdasarkan Agama atau Kepercayaan 1981 menyatakan bahwa, "Setiap orang memiliki hak atas kebebasan berpikir, berkeyakinan dan beragama hak ini meliputi kebebasan untuk mengubah agama atau kepercayaannya, dan kebebasan baik sendiri atau dalam bersama dengan orang lain, baik secara publik maupun pribadi untuk memanifestasikan agama atau kepercayaannya dalam pengajaran, praktek, ibadah dan ketaatan".

Jadi jika kita bicara tentang kebebasan beragama kita tidak hanya membahas tentang kebebasan beragama dalam hal memeluk agama saja akan tetapi kebebasan setiap pemeluk agama untuk dapat menjalankan agamanya masing-masing. ${ }^{12}$ Kebebasan beragama sendiri dapat ditafsirkan secara berbeda-beda oleh berbagai kebudayaan yang mana hal ini telah mewarnai pada saat penyusunan UDHR terkait dengan hak-hak yang harus dilindungi. ${ }^{13}$ Menurut Pasal 9 ECHR, keebebasan beragama atau kepercayaan dapat terbagi menjadi dua bagian yaitu kebebasan untuk memilih atau menganut agama atau kepercayaan atas keinginannya sendiri (forum internum) dan kebebasan untuk

12 Brice Dickson, op.cit

13 Anat Scolnicov, 2011, The Right to Religious Freedom in International Law Between Group Rights and Individual Rights, New York: Routledge, hlm 23. 
memanifestasikan agama dan kepercayaan yang dianutnya (forum eksternum). ${ }^{14}$

Kebebasan beragama merupakan hak yang fundamental yang merupakan salah satu hak dari 16 hak yang tidak dapat dikurangi dalam keadaan apapun (non-derogable rights). ${ }^{15}$ Hak untuk beragama merupakan hak yang tidak dapat diambil oleh siapapun (unalienable) karena hak untuk beragama ditentukan oleh dirinya sendiri dan tanpa ada paksaan dan dipaksakan oleh orang lain. ${ }^{16}$ Oleh karena itu dalam pelaksanaanya negara dalam hal ini tidak boleh melakukan intervensi terhadap hak kebebasan bergama akan tetapi harus dapat memberikan suatu jaminan kepada warga negaranya untuk dapat menjalankan agamanya tanpa ada gangguan dari pihak manapun. ${ }^{17}$

Seperti yang telah dijelaskan di atas bahwa kebebasan beragama sendiri terbagai menjadi 2 yaitu forum internum dan forum eksternum, pada dasarnya kebebasan yang bersifat absolut dan tidak memperkenankan adanya suatu intervensi dari negara adalah kebebasan beragama dalam konteks forum internum. Sedangkan dalam konteks forum eksternum bukanlah suatu hak yang absolut sehingga dalam pelaksanaannya masih dapat dibatasi oleh negara (Pasal 9 ayat 2 ECHR). Untuk dapat menjamin ini negara juga harus memastikan bahwa tidak ada diskriminasi terhadap seseorang atau sekelompok orang yang dilakukan atas nama agama. ${ }^{18}$ Negara harus melakukan berbagai upaya baik melalui undang-undang ataupun kebijakan yang melarang segala bentuk diskriminasi dan perbuatan intoleran yang didasarkan atas agama atau kepercayaan (Pasal 4 ayat (2)

14 Merilin Kiviorg, 2010, Collective Religious Autonomy under European Convention on Human Rights: The UK Jewish Free School Case in International Perspective, European University Institute Florence, Max Weber Programme, hlm 3, http:// cadmus.eui.eu/ bitstream/ handle/ 1814/ 15236/ MWP 2010 40.pdf diakses pada 18 Mei 2011.

15 Paris Minimum Standards of 1984

16 McConnell, Garvey dan Berg, 2006, Religion and The Constitution, $2^{\text {nd }}$ Edition, New York: Aspen Publisher, $\mathrm{hlm} 49$

17 Brice Dickson, op.cit.

18 Pasal 4 ayat (1) Declaration on the Elimination of All Forms of Intolerance and of Discrimination Based on Religion or Belief 1981
Declaration on the Elimination of All Forms of Intolerance and of Discrimination Based on Religion or Belief 1981). Pelaksanaan kebebasan beragama sendiri pada dasarnya tidak dapat terlepas dari ketentuan Pasal 19, Pasal 20 ayat 2 dan Pasal 27 ICCPR.

\section{Pembatasan-PembatasanTerhadap Kebebasan Beragama}

Hak-hak sipil dan politik adalah hak yang dilindungi berdasarkan ICCPR begitu juga dalam berbagai konvensi lain seperti the European Convention, dan the American Convention. Dalam beberapa hal para pembentuk ketentuan ini mencoba untuk memberikan suatu peluang bagi pemerintah untuk dapat membentuk suatu pembatasan atas berbagai hak-hak sipil dan politik. Terdapat beberapa ketentuan yang memperkenankan dibatasinya suatu hak termasuk hak tentang kebesan berpindah, agama, berekspresi, berkumpul dan berpendapat yang mana tidak dapat dibatasi kecuali untuk melindungi keamanan nasional, keamanan masyarakat, ketertiban umum, kesehatan atau moral atau hak-hak dan kebebasan lainnya. ${ }^{19}$ Oleh karena itu pembatasan terhadap kebebasan beragama diperkenankan berdasarkan ketentuan Pasal 18 ayat (3) bahwa kebebasan untuk memanifestasikan agama atau kepercayaan dapat dibatasi hanya oleh hukum dan hanya diperlukan untuk melindungi keamanan masyarakat, kepentingan, kesehatan atau moral atau hak-hak fundamental lainnya.

Dapat disimpulkan bahwa pembatasan ini diperkenankan dan dibatasi secara sempit yaitu hanya terhadap lima ketentuan. Pertama, pembatasan-pembatasan demi perlindungan keamanan publik; kedua, pembatasan-pembatasan untuk melindungi tatanan/ketertiban publik; ketiga, pembatasan-pembatasan dalam rangka perlindungan kesehatan publik; keempat, pembatasan-pembatasan dalam rangka perlindungan moral; dan kelima, pembatasan-pembatasan

19 ICCPR, supra note 41, Arts. 12(3), 18(3), 19 (3), 2 1,22 (2); European Convention, supra note 41, Arts. 9(2), 10(2), 11 (2); American Convention, w/ »m note 41, Arts. 12(3), 13(2), 15, 16(2), 22(3). 
demi melindungi hak-hak dan kebebasan fundamental orang-orang lain.

Selain itu pembatasan terkait dengan manifestasi agama atau keyakinan seseorang ini hanya diperbolehkan jika pembatasan tersebut tidak diskriminatif. ${ }^{20}$ Terkait dengan hal ini Indonesia sendiri memiliki suatu pengaturan yang merupakan suatu pembatasan yaitu tentang ij in pendirian rumah ibadah. Mengapa dikatakan sebagai pembatasan karena pemeluk agama tidak dapat secara langsung membangun sebuah rumah ibadah yang dimaksudkan sebagai manifestasi kepercayaannya tanpa ada ijin dari pemerintah setempat termasuk juga penduduk disekitar rumah ibadah tersebut akan didirikan.

Peraturan tentang ijin pembangunan rumah ibadah ini diatur dalam Peraturan Bersama Mentri Agama dan Mentri Dalam Negeri Nomor 9 dan Nomor 8 tahun 2006 tentang Pedoman Pelaksanaan Kepala Daerah/Wakil Kepala Daerah dalam Pemeliharaan Kerukunan Umat Beragama, Pemberdayaan Forum Kerukunan Umat Beragama dan Pendirian Rumah Ibadah. Berdasarkan ketentuan ini untuk membangun sebuah rumah ibadah pemeluk agama harus memenuhi persyaratan berupa:

(1) Adanya keperluan nyata dan sungguhsungguh berdasarkan komposisi jumlah penduduk bagi pelayanan umat beragama yang bersangkutan di wilayah kelurahan/ desa (Pasal 13 ayat (1) SKB 2 Menteri No. 9 Tahun 2006).

(2) Pendirian rumah ibadah sendiri harus pendirian rumah ibadat harus memenuhi persyaratan khusus meliputi :

a. daftar nama dan Kartu Tanda Penduduk pengguna rumah ibadat paling sedikit 90 (sembilan puluh) orang yang disahkan oleh pejabat setempat sesuai dengan tingkat batas wilayah sebagaimana dimaksud dalam Pasal 13 ayat (3);

20 Manfred Nowak dan Tanja Vospernik, 2010, Pembatasan-Pembatasan yang Diperbolehkan terhadap Kebebasan Beragama atau Berkeyakinan, dalam Kebebasan Beragama atau Berkeyakinan Seberapa J auh?, Yogyakarta: Kanisius, hlm 230 b. dukungan masyarakat setempat paling sedikit 60 (enam puluh) orang yang disahkan oleh lurah/ kepala desa;

c. rekomendasi tertulis kepala kantor departemen agama kabupaten/ kota; dan

d. rekomendasi tertulis FKUB kabupaten / kota.

(3) Dalam hal persyaratan sebagaimana dimaksud pada ayat (2) huruf a terpenuhi sedangkan persyaratan huruf $b$ belum terpenuhi, pemerintah daerah berkewajiban memfasilitasi tersedianya lokasi pembangunan rumah ibadat.

\section{Analisis Terhadap SKB Pendirian Rumah Iba- dat}

Pendirian rumah ibadat apabila dilihat dalam konteks kebebasan beragama masuk ke dalam ranah forum eksternum yang dapat diartikan bahwa negara dapat membatasi pelaksanaanya (Lihat Pasal 18 ayat 3 ICCPR, Pasal 9 ayat (2) European Convention on Human Rights dan pasal 12 ayat (3) American Convention on Human Rights ), akan tetapi pembatasan harus dilakukan dengan Undang-Undang. UU No. 39 tahun 1999 tentang Hak Asasi Manusia juga meligitimasi pembatasan ini yang diatur dalam Pasal 70. ${ }^{21}$ Pembangunan rumah ibadah adalah salah satu bentuk penganut suatu agama untuk mewadahi kegiatan keagamaan. Pembangunan rumah ibadah termasuk dalam salah satu bentuk kebebasan yaitu kebebasan untuk beribadah (freedom of worship). ${ }^{22}$ Pembangunan rumah ibadah tentunya berkaitan dan dapat berbenturan dengan hak-hak asasi lainnya antara lain tentang ketertiban umum.

21“ Dalam menjalankan hak dan kebebasannya, setiap orang wajib tunduk kepada pembatasan yang ditetapkan oleh Undang-undang dengan maksud untuk menjamin pengakuan serta penghormatan atas hak dan kebebasan orang lain dan untuk memenuhi tuntutan yang adil sesuai dengan pertimbangan moral, keamanan, dan ketertiban umum dalam suatu masyarakat demokratis."

22 Freedom of Worship terdapat dalam Pasal 6 Declaration on the Elimination of All Forms of Intolerance and of Discrimination Based on Religion or Belief 1981 yang menyatakan bahwa dalam hak memanifestasikan agama termasuk hak untuk beribadah dan berkumpul serta hak untuk mendirikan rumah ibadah. 
Jika dilihat dari perspektif pemerintah, dapat dipahami mengapa pemerintah mencoba membuat suatu pengaturan terkait dengan pembangunan rumah ibadah melalui SKB Pendirian Rumah Ibadah tahun 2006, yaitu untuk menjaga ketertiban umum, mengingat negara Indonesia adalah negara yang pluralis yang memiliki berbagai agama dan kepercayaan. Pada dasarnya ketentuan ini adalah prosedur administratif, yang berarti sepanjang aturan administratif dipenuhi sejogjanya tidak akan menimbulkan konflik. Pengaturan tentang ijin pembangunan rumah ibadah ini apabila ditinjau dari konteks ham pada dasarnya diperkenankan sepanjang untuk mencegah kekacauan publik. ${ }^{23}$

Sehingga secara regulasi SKB Pendirian Rumah Ibadah tahun 2006 adalah sesuatu yang diperkenankan oleh prinsip-prinsip hak asasi manusia. Akan tetapi dalam penerapannya mengalami berbagai hambatan. Penyegelan rumah ibadah yang terjadi di Bekasi dan Tanggerang menunjukkan bahwa meskipun aturan administratif telah terpenuhi tidak menjamin pembangunan rumah ibadah dapat dijalankan dengan baik. Beberapa alasan yang dikemukakan oleh pemerintah setempat adalah bahwa pembangunan rumah ibadah (gereja) tersebut mengganggu ketertiban umum masyarakat sekitar. Pertanyaannya adalah meskipun telah mendapat persetujuan secara administratif dari warga sekitar tempat pembangunan gereja tersebut akan tetapi pembangunan gereja juga tidak dapat dilaksanakan.

Bagaimana dengan agama/aliran yang tidak termasuk salah satu dari agama resmi di Indonesia apakah akan mendapatkan hak untuk membangun rumah ibadahnya? Secara konstitusional hal ini tentu diperkenankan karena UUD 1945 tidak melarang hal tersebut akan tetapi jika melihat pada persyaratan yang dibutuhkan untuk pembangunan rumah ibadah berdasarkan SKB Menteri tentang pembangunan rumah ibadah, tentu saja hal tersebut tidak dimungkinkan dan hal ini terjadi pada kasus Ahmadiyah. Karena ijin pembangunan rumah ibadah tersebut sudah dipastikan tidak akan dikeluarkan,

23 Manfred Nowak dan Tanja Vospernik, op.cit, hlm 208 atau dengan kata lain agama yang tidak resmi tidak akan memperoleh hak untuk membangun rumah ibadah. ${ }^{24}$

Jadi meskipun pembatasan tersebut ditujukan untuk ketertiban umum namun pada akhirnya pembatasan ini melanggar hak asasi manusia itu sendiri terkait dengan pembatasan kebebasan beragama. ${ }^{25}$ Karena meskipun berdasar Pasal 18 ayat 3 ICCPR dan Pasal 70 UU No 39 tahun 1999 tentang HAM pembatasan oleh pemerintah diperkenankan tetapi hal ini harus dipahami bersama-sama dengan prinsip non intervensi dan non diskriminasi (Pasal 4 ayat (2) Declaration on the Elimination of All Forms of Intolerance and of Discrimination Based on Religion or Belief 1981) dimana negara harus menjamin hak setiap warga negara untuk memanifestasikan atau agama atau kepercayaannya tanpa mendapatkan suatu diskriminasi baik oleh pemeluk agama lain maupun oleh kebijakan yang dibuat oleh pemerintah sendiri. Dalam membuat suatu pembatasan negara ti-dak boleh mengutamakan salah satu agama/ kepercayaan dibandingkan dengan agama yang lain, serta mengambil kebijakan yang lebih menguntungkan salah satu agama/kepercayaan dibandingkan yang lain. ${ }^{26}$

Permasalahan pembangunan rumah ibadah di Indonesia mempermasalahkan berbagai faktor yaitu agama mayoritas dan agama minoritas, agama yang resmi dan agama yang tidak resmi. Apabila dilihat dari indikator tersebut di atas maka terlihat suatu diskriminasi yang mana perlakuan terhadap agama mayoritas tentu akan berbeda dengan agama minoritas. Ijin pembangunan rumah ibadah bagi agama mayoritas tentu bukan suatu permasalahan, akan tetapi tidak berlaku sebaliknya.

Apabila suatu agama/kepercayaan tidak diakui sebagai salah satu agama maka dia akan kehilangan haknya sebagai penganut agama di Indonesia, kecuali memilih salah satu dari ke-

24 Caveat, "Freedom of Religion in Indonesia: Multiple Choices not Short Answers", Indonesian Monthly Human Rights Analysis, 09 (II) February 2010, hlm 4.

25 Lihat kasus Mannousakis v Greece dan Tsavaehidis v. Greece.

26 J. Raz, 1988, The Morality of Freedom, OUP, Oxford, hIm 110. 
enam agama yang ada dan tentu saja pemeluk agama ini tidak akan diberikan haknya antar lain seperti hari libur keagamaan apalagi untuk membangun rumah ibadah. Untuk kasus Ahmadiyah, sudah dapat dipastikan bahwa umatnya tidak dapat mendirikan rumah ibadah karena Ahmadiyah sendiri tidak diakui sebagai salah satu agama resmi di Indonesia sehingga tidak mendapatkan haknya untuk membangun rumah ibadah.

Pada dasarnya pembatasan kebebasan beragama diperkenankan sepanjang berkaitan dengan forum externum apabila ditujukan untuk menjaga ketertiban umum dan dilaksanakan tanpa ada diskriminasi. Akan tetapi pembatasan ini hanya boleh didasarkan pada undangundang. SKB 2 Menteri tahun 2006 tentang pendirian rumah ibadah, bukanlah merupakan produk undang-undang sehingga dapat dikatakan bahwa SKB tersebut merupakan produk yang inkonstitusional ${ }^{27}$ oleh karena itu tidak dapat dijadikan sebagai dasar pembatasan kebebasan beragama dalam hal ini dalam hal pendirian rumah ibadah, meskipun ditujukan untuk menjaga ketertiban umum. Oleh karena itu jika pemerintah ingin melakukan pembatasan dalam pembangunan rumah ibadah maka pemerintah harus membatasi hal tersebut melalui peraturan perundang-undangan sehingga memiliki kekuatan hukum yang sah.

\section{Solusi Penegakan Kebebasan Menjalankan Ibadah}

Pembangunan rumah ibadah sendiri pada dasarnya adalah bagian dari hak untuk menjalankan agama atau kepercayaan ${ }^{28}$. Permasalahan tentang kebebasan menjalankan ibadah ini menurut saya tidak akan pernah selesai hanya dengan mengeluarkan ketentuan undangundang saja tanpa ada komitmen yang jelas dari seluruh pemangku kepentingan khususnya di Indonesia dengan keberagamannya ini. Se-

27 Merilin Kiviorg, "The Permisible Scope of Legal Limitations on the Freedom of Religionor Belief in Estonia", Emory International Law Review, 19 year 2005, hlm 757.

28 Asma J ahangir, Implementation Of General Assembly Resolution 60/251 Of 15 March 2006 Entitled "Human Rights Council", A/ HRC/ 4/21/ Add. 1, 8 Maret 2007 perti dijelaskan sebelumnya agama pada dasarnya adalah hubungan yang pribadi antara seseorang dengan Tuhannya yang mana hal ini sejajar dengan bagaimana dia berhubungan dengan manusia lainnya. Karena tanpa ada hubungan yang baik secara pararel maka tidak akan terwujud hubungan yang baik dengan Tuhan secara vertikal.

Meskipun negara Indonesia mengakui adanya kebebasan beragama akan tetapi pembatasan-pembatasan yang diberikan oleh negara terhadap kebebasan beragama ini sangat banyak. Pembatasan ini diawali dengan adanya ketentuan tentang agama yang diakui hanya 6 (enam) agama dan satu aliran kepercayaan. apabila melihat ketentuan tersebut maka hanya agama-agama tersebut yang akan mendapatkan perlindungan dan jaminan dari pemerintah sedangkan bagi penganut agama di luar agama yang diakui akan mendapatkan kesulitan untuk mendapatkan hak-haknya sebagai warga negara. Hal ini dapat dilihat dari kasus Ahmadiyah yang mana tidak diakui sebagai agama. Menurut penulis hal ini tentu saja bertentangan dengan konstitusi itu sendiri serta ketentuan internasional yang telah diratifikasi oleh Indonesia yang tentunya mewajibkan Indonesia untuk menghormati perjanjian tersebut untuk mematuhinya.

Bagi agama-agama "resmi", seharusnya berdasarkan ketentuan Pasal 29 (2) UUD 1945 mendapatkan kebebasan untuk menjalankan ibadahnya pada pelaksanaannya tetap mendapat pembatasan-pembatasan yaitu melalui ketentuan Perihal pendirian Peraturan Bersama Menteri Agama Dan Menteri Dalam Negeri No. 9 Tahun 2006 dan No. 8 Tahun 2006 Tentang Pedoman Pelaksanaan Tugas Kepala Daerah/ Wakil Kepala Daerah Dalam Pemelihara Kerukunan Umat Beragama, Pemberdayaan Forum Kerukunan Umat Beragama, dan Pendirian Rumah Ibadat (selanjutnya akan disebut SKB Pendirian Rumah Ibadat). Di satu sisi ketentuan ini khususnya tentang pembatasan diperkenankan karena memang diatur dalam UU No 39 tahun 1999 tentang Hak Asasi Manusia. Pembatasan ini tentu saja tidak boleh didasarkan atas 
diskriminasi atau bahkan menghilangkan hakhak yang dimiliki oleh kaum minoritas. Peraturan pembangunan rumah ibadah sendiri ditujukan untuk menjamin ketertiban dan keharmonisan antar umat beragama. Secara sudut pandang hukum hal ini lebih kepada aturan administratif untuk memberikan suatu keadilan. Tetapi pada pelaksanaannya meskipun aturan adminstratif terpenuhi bukan berarti pembangunan rumah ibadah dapat dilaksanakan.

Penyelesaian terhadap konflik keberagaman di Indonesia sendiri pada dasarnya tidak cukup hanya dilakukan melalui undang-undang atau melalui jalur hukum semata. Jika hanya mekanisme itu yang diambil, maka persoalan konflik keagamaan ini akan tetap berlangsung dan berpotensi semakin meluas dan meruncing.

Pemerintah selama ini selalu bertindak pada saat pelanggaran telah terjadi (represif) dan tentu saja setelah ada desakan dari masyarakat. Agama seringkali dijadikan sebagai sarana politis dari kelompok-kelompok tertentu untuk melancarkan jalur politik mereka. Solusi yang terbaik adalah pada proses pencegahan (preventif). Dalam hal ini diperlukan kerjasama yang optimal dari para pemangku kepentingan dan adanya kesadaran dari masing-masing pihak untuk mau menjalin komunikasi serta menghargai umat lainnya.

Pengaturan kebebasan beragama melalui hukum internasional merupakan sesuatu yang abstrak dan akan sangat tergantung pada keinginan masing-masing negara untuk melaksanakannya. Indonesia meskipun telah meratifikasi dan mengakui kebebasan beragama tetap belum bisa mengakomodasi kebebasan ini dengan baik.

Penulis sependapat dengan apa yang dinyatakan oleh Tore Lindholm, ${ }^{29}$ bahwa yang terpenting bukanlah para pemeluk agama menghargai kepercayaan dan pengamalan agama lain atau apakah mereka mengakui jalan keselamatan alternative akan tetapi apakah

29 Tore Lindholm, 2010, Justifikasi Filosofis dan Keagamaan terhadap Kebebasan Beragama atau Berkeyakinan dalam Kebebasan Beragama atau Berkeyakinan Seberapa Jauh?, Yogyakarta: Kanisius, hlm 141 para pihak dapat mendukung doktrin publik tentang martabat inheren setara dan kebebasan semua manusia yang tidak dapat dicabut tanpa tergantung dengan pandangan agama, pandangan hidup atau perbedaan lain pada diri mereka dan masing-masing pihak mau memahami dan mempercayai bahwa pihak lain juga sama-sama mendukung kebebasan beragama atau berkeyakinan yang umum.

Permasalahan pembangunan rumah ibadah tidak akan pernah selesai sepanjang setiap pihak tidak mau memahami bahwa setiap orang memiliki hak yang sama untuk melaksanakan agamanya, sebaik apapun aturan yang dibuat apabila orang yang menjalankan tidak memahaminya maka aturan tersebut tidak akan berguna. Pemerintah dalam kasus kebebasan beragama di Indonesia merupakan aktor kunci ${ }^{30}$ dalam kebijakan-kebijakan yang bersifat diskriminatif dengan cara memihak salah satu kelompok agama dan menerapkan diskriminasi terhadap agama, kepercayaan dan filosofi-filosofi lainnya.

Terhadap pembangunan rumah ibadah jelas terlihat bahwa pemerintah bersikap berat sebelah dan lebih memihak pada golongan mayoritas. Karena kebijakan yang diambil selalu berdasarkan desakan dari kelompok yang mengatasnamakan kelompok mayoritas. Pemerintah juga terkesan membiarkan para pelaku untuk tidak mendapatkan suatu penegakan hukum yang sesuai. Hal penting yang harus dilakukan oleh pemerintah tidak hanya menyelesaikan masalah pertikaian konflik keagamaan ini setelah peristiwa terjadi akan tetapi bagaimana kita menjaga kerukunan umat beragama ini dimasa yang akan datang. Hal yang terpenting adalah mendorong saling pengertian, toleransi dan penghormatan sehubungan dengan kebebasan beragama dalam rangka menjamin terlaksananya prinsip perlindungan hak asasi manusia yang telah diatur dalam konstitusi. ${ }^{31}$

30 Manfred Nowak dan Tanja Vospernik, op.cit, , hlm 201.

31 Lihat Pembukaan, paragraf. 5, Declaration on the Elimination of All Forms of Intolerance and of Discrimination Based on Religion or Belief, adopted 18 J an. 1982, G.A. Res. 55, 36 U.N. GAOR Supp. (No. 51), U.N. Doc. A/ RES/ 36/ 55 (1982) 
Pemerintah tidak dapat menganggap ringan permasalahan ini, karena banyak kejahatan berskala besar yang didasarkan atas motif agama seperti halnya genosida. Jika pemerintah tidak mengambil langkah serius maka kekhawatiran bahwa akan terjadi suatu konflik yang berkepanjangan di kemudian hari seperti halnya yang terjadi antara Israel dan Palestina, dimana Indonesia pernah mengalami ini melalui kejadian di Maluku dan Poso.

Dialog pada saat ini bukan jalan keluar karena hanya menjangkau golongan atas saja tidak sampai ke golongan akar rumput. Dialog yang selama ini dilakukan hanya sebatas diskusi, seminar dan tentu saja tidak akan memberikan suatu perubahan yang signifkan. Perubahan sampai ke akar rumput tidak cukup hanya dengan dialog tetapi butuh hal yang lebih penting yaitu pendidikan yang dapat mengubah pola pikir masyarakat, untuk lebih menghargai perbedaan.

Jika pemerintah berani mengambil langkah tegas untuk menegakkan hukum terhadap para pelanggar kebebasan beragama ini merupakan suatu langkah yang baik yang dapat memberikan suatu efek jera bagi para pelaku kekerasan. Upaya lain terkait dengan represif adalah membubarkan dan menindak tegas organisasi kemasyarakatan yang bersifat anarkis dan berbau SARA.

Toleransi memegang peranan penting khususnya dalam pembangunan rumah ibadah. Toleransi yang berasal dari bahasa latin tolerare memiliki pengertian membiarkan mereka yang berpikiran lain atau berpandangan lain tanpa dihalang-halangi. Menurut UNESCO dalam Declaration of Principles in Tolerance pasal 1 menjelaskan bahwa toleransi adalah penghormatan, penerimaan dan apresiasi terhadap perbedaan yang ada di dunia. Toleransi adalah harmonis dalam perbedaan, yang bukan saja suatu kewajiban moral akan tetapi suatu hal yang diperpersyaratkan dalam bidang politik dan hukum. Toleransi harus dilaksanakan oleh individu, kelompok dan masyarakat. ${ }^{32}$

32 Calros Valderrama Adriansén, 3 April 2007; Tolerance and Religious Freedom: The Struggle in Peru To
Toleransi sendiri terbagi dua yaitu toleransi formal dan toleransi material. Toleransi formal berarti membiarkan pandangan-pandangan dan praktik-praktik politik atau agama yang tidak sesuai dengan pandangan kita sejauh tidak mengganggu. ${ }^{33}$ Toleransi bukan berarti kita bersikap sangat apatis menjadi tidak peduli. Toleransi sangat diperlukan dalam kebebasan beragama karena setiap orang yang memiliki agama atau kepercayaan tentunya memiliki hak dan kewajiban untuk menjalankan agamanya tersebut. jika tidak ada toleransi tentu akan terdapat pihak-pihak yang haknya tidak tersampaikan dan pada umumnya dapat dipastikan bahwa yang akan menjadi korban adalah kelompok minoritas.

SKB Pendirian Rumah Ibadah hanyalah ketentuan yang bersifat mengatur dan pelaksanaanya sangat tergantung dari toleransi masingmasing pihak untuk dapat menerima pendirian rumah ibadah di suatu daerah tertentu. Adanya penyerangan terhadap pendirian rumah ibadah menunjukkan suatu fenomena bahwa sudah berkurangnya budaya toleransi di Indonesia dan kurangnya pemahaman masyarakat tentang kehidupan yang maj emuk.

Meskipun di beberapa daerah upaya membangun toleransi ini masih ada seperti di daerah Mopuya, desa di Kecamatan Dumoga Utara, Kab Bolmong, Provinsi Sulawesi Utara yang mana masalah pembangunan rumah ibadah bukanlah suatu persoalan. Di desa pembangunan rumah ibadah dilakukan dalam satu komplek dari lahan yang disediakan oleh Pemerintah. ${ }^{34}$

Persoalan penyegelan dan penyerangan gereja dan tempat beribadah Ahmadiyah pada dasarnya dapat dipandang sebagai dua hal yang

Tolerate Multiple Cultures in Light of Principles of Religious Freedom. Brigham Young University Law Review [serial online]. hlm 776-777.

33 Andreas A Yewangoe, 2009, Regulasi Toleransi dan Pluralisme Agama di Indonesia, dalam Merayakan Kebebasan Beragama "Bunga Rampai Menyambut 70 tahun Djohan Effendi", Jakarta:ICRP dan Kompas, hlm 80-81.

34 Sumanto Al Qurtuby, 2009, Pluralisme, Dialog, dan Peacebuilding Berbasis Agama di Indonesia, dalam Merayakan Kebebasan Beragama "Bunga Rampai Menyambut 70 tahun Djohan Effendi", Jakarta: ICRP dan Kompas, hlm, 173. 
sama tetapi berbeda. Persamaannya adanya pembatasan untuk menjalankan ibadah, perbedaannya adalah untuk penyegelan dan penyerangan gereja bahwa gereja adalah tempat beribadah umat Kristiani yang merupakan salah satu dari agama resmi di Indonesia sedangkan Ahmadiyah merupakan agama yang tidak diakui sebagai salah satu agama resmi. Secara regulasi maka pada kasus yang pertama dapat dikatakan meskipun merupakan agama resmi akan tetapi jaminan yang diberikan negara terhadap hak untuk menjalankan ibadah tetap tidak terpenuhi. Untuk Ahmadiyah, pada dasarnya tidak di akui secara hukum sehingga memang Ahmadiyah tentunya tidak dapat jaminan dari negara untuk melaksanakan ibadahnya meskipun jika dilihat dari konteks kebebasan beragama hal ini merupakan suatu pelanggaran.

Jadi penyelesaian terhadap kasus penyegelan gereja masih ada kemungkinan penyelesaian secara hukum, akan tetapi untuk Ahmadiyah tentunya lebih sulit karena Ahmadiyah bukanlah agama yang legal berdasarkan hukum Indonesia. Untuk mengatasi ini diperlukan suatu kedewasaan dari setiap warga negara dan tentunya pemerintah untuk lebih dapat bersikap bijaksana. Keterbukaan menjadi kata kunci sekaligus prasyaratan pertemuan agama yang sehat dan dinamis serta jalan terciptanya perdamaian global antar umat beragama. ${ }^{35}$

Jika kita melihat kondisi yang ada maka kurangnya toleransi ini harus diperbaiki sesegera mungkin dan hal ini sejalan dengan apa yang terdapat dalam Commission on Human Rights resolution 2003/54 tentang Elimination Of All Forms of Religious Intolerance dimana hasil rekomendasi berupa mendorong negara untuk memastikan bahwa konstitusi negara dan sistem legislatif memberikan jaminan terhadap kebebasan beragama, dalam hal ini menurut pandangan penulis Indonesia pada dasarnya secara konstitusi telah memberikan jaminan akan tetapi ada beberapa perundang-undangan dan peraturan di bawah undang-undang yang bertentangan dengan konstitusi itu sendiri seperti

35 Ibid, hlm 193. adanya pembatasan tentang agama resmi yang diakui oleh pemerintah.

Negara juga sampai saat ini belum bisa menjamin untuk memberikan perlindungan kepada setiap warganegaranya terkait dengan kebebasan beragama dan masih banyak terdapat praktik-praktik pembiaran terkait dengan pelanggaran kebebasan beragama. ${ }^{36}$ Pengakuan terhadap hak-hak warga negara untuk dapat beribadah dengan memperoleh tempat beribadah yang layak juga belum dapat terpenuhi peraturan tentang pendirian rumah ibadah yang ditujukan untuk menjaga ketertiban umum sebaliknya dijadikan sebagai sarana pembatasan untuk pembangunan rumah ibadah itu sendiri. ${ }^{37}$

Upaya pemerintah untuk mengurangi rasa kebencian dan meningkatkan toleransi antar umat beragama juga belum memadai pemerintah hanya selalu menggunakan dialog tanpa ada tindak lanjut. ${ }^{38}$ Tanggung jawab untuk menjamin kebebasan beragama/kepercayaan tidak hanya menjadi tanggung jawab pemerintah semata-mata akan tetapi merupakan tanggung jawab penuh dari para pemimpin agama masing-masing. Para pemimpin agama seharusnya dapat memberikan teladan serta membawa pemeluknya untuk lebih dapat menghargai dan mengembangkan toleransi antar pemeluk agama untuk dapat hidup berdampingan secara damai. ${ }^{39}$

Upaya yang dilakukan oleh pemerintah sejauh ini hanyalah sebagai mengeluarkan ketentuan-ketentuan di atas kertas saja seperti halnya ketentuan yang terbaru yaitu tentang Instruksi Menteri Agama Nomor 2 tahun 2011 tentang Antisipasi Terhadap Timbulnya Kerawanan/Konflik Kerukunan Umat Beragama.

36 Commission on Human Rights resolution 2003/54 tentang Elimination of all forms of religious intolerance, Pasal 4 point $b$

37 Commission on Human Rights resolution 2003/54 tentang Elimination of all forms of religious intolerance, Pasal 4 point $d$

38 Commission on Human Rights resolution 2003/54 tentang Elimination of all forms of religious intolerance, Pasal 4 point $c$

39 Freedom to Believe: Upholding the Standard of the Universal Declaration of Human Rights Bahá'í International Community's Statement on the Freedom of Religion or Belief October 2005, http:// statements. bahai. org/ 05-1001. htm 
Ketentuan ini hanyalah berisi imbauan untuk berkoordinasi dan mensosialisasikan kerukunan antar umat beragama.

Aturan pembangunan rumah ibadah menurut penulis masih diperlukan untuk mewujudkan suatu ketertiban umum, akan tetapi yang terpenting bukanlah aturan melainkan bagaimana para pihak dapat saling menghormati dan menghargai kebebasan pemeluk agama lain untuk dapat menjalankan ibadahnya. Oleh karena itu memupuk toleransi merupakan hal yang harus dilakukan saat ini oleh seluruh warga Indonesia dengan didukung oleh semua pihak yaitu pemerintah, pemimpin agama serta lingkungan pendidikan. Pemerintah juga harus memberikan jaminan yang tegas tanpa mendiskriminasikan kelompok tertentu untuk selalu menindak tegas pelanggaran-pelanggaran yang terkait dengan kebebasan menjalankan ibadah terkait dengan pembangunan rumah ibadah.

\section{Penutup \\ Simpulan}

SKB 2 menteri tahun 2006 terkait pembangunan rumah ibadah yang mana ditujukan untuk menjaga ketertiban umum secara hak asasi manusia diperkenankan karena pembangunan rumah ibadah merupakan bagian dari forum eksternum dimana kebebasan beragama bukan dipandang sebagai sesuatu yang absolut. Akan tetapi pelaksanaan forum eksternum sendiri tentu harus dengan tetap memperhatikan prinsip-prinsip non-diskriminasi dan mencegah intoleransi antar umat beragama. Akan tetapi pada pelaksanaanya SKB tersebut melanggar prinsip-prinsip HAM yang lain, karena SKB tersebut bukanlah merupakan undang-undang yang dihasilkan oleh lembaga legislatif sehingga dapat dikategorikan merupakan suatu hal yang inkonstitusional. Pada tataran pelaksanaanya SKB tersebut menimbulkan suatu diskriminasi terhadap kelompok agama tertentu khususnya minoritas dan menimbulkan berbagai konflik yang ditimbulkan karena kurangnya toleransi antar umat beragama.

Upaya yang harus dilakukan untuk mencegah konflik terkait dengan pendirian rumah ibadah adalah dengan memupuk rasa toleransi antar umat beragama yang dimulai sejak dini yang dimulai dari kelompok terkecil dalam masyarakat yaitu keluarga. Di samping itu pemerintah juga harus bertindak lebih tegas serta non-diskriminatif terhadap pemeluk agama dan kepercayaan baik golongan mayoritas maupun minoritas dalam rangka menjaga ketertiban dan penghormatan hak asasi manusia khususnya kebebasan bergama dan menjalankan ibadah.

\section{Saran}

Adapun saran penulis dalam hal ini adalah bahwa pembatasan yang dilakukan oleh negara terkait dengan pembangunan rumah ibadah di masa yang akan datang masih diperlukan sepanjang kebijakan yang dibuat didasarkan atas prinsip non-diskriminasi dan netral begitu juga pada pelaksanaanya. Pembatasan yang terkait dengan kebebasan beragama dalam hal ini pembangunan rumah ibadah harus didasarkan pada perundang-undangan yang dihasilkan oleh lembaga legislatif.

Selain adanya suatu jaminan dan perlindungan yang diberikan oleh negara terkait dengan kebebasan beragama, adalah menjadi tugas setiap pemangku kepentingan dan juga warga negara untuk semakin memupuk kesadaran dan meningkatkan toleransi antar umat beragama.

\section{Daftar Pustaka}

Adriansén, Calros Valderrama. 3 April 2007. Tolerance and Religious Freedom: The Struggle in Peru To Tolerate Multiple Cultures in Light of Principles of Religious Freedom. Brigham Young University Law Review [serial online];

Ardianto, Sigit. 2009. From Secularism into Modifed Pluralism: Comprehensive Application of J ohn Rawls's J ustice as Fairness Theory in Defining State and Religion Relationship. Cornell law Library;

Baidhawi, Zakiyuddin. 2005. Kredo Kebebasan Beragama. Jakarta: PSAP Muhammadiyah;

Caveat; "Freedom of Religion in Indonesia: Multiple Choices not Short Answers"; 
Indonesian Monthly Human Rights AnaIysis, 09 (II) February 2010;

Dickson, Brice. "The United Nations and Freedom of Religion". The International and Comparative Law Quarterly, 44 (2) April, 1995;

Henkin, Louis. "Religion, Religions, and Human Rights". The Journal of Religious Ethics, 26 (2) Fall, 19989, URL: http:// www.jstor.org/ stable/ 40008655 diakses pada: 25/ 08/ 2010 05: 12;

J ahangir, Asma. Implementation Of General Assembly Resolution 60/251 Of 15 March 2006 Entitled "Human Rights Council", A/ HRC/ 4/ 21/ Add. 1, 8 Maret 2007;

Kiviorg, Merilin. "The Permisible Scope of Legal Limitations on the Freedom of Religionor Belief in Estonia". Emory International Law Review, 19 year 2005;

Kiviorg, Merilin. 2010. Collective Religious Autonomy under European Convention on Human Rights: The UK Jewish Free School Case in International Perspective. European University Institute Florence, Max Weber Programme, http:// cadmus. eui. eu/ bitstream/ handle/ 1814/ 15236/ MWP 2010 40.pdf diakses pada 18 Mei 2011;

Lindholm, Tore. 2010. Justifikasi Filosofis dan Keagamaan terhadap Kebebasan Beragama atau Berkeyakinan dalam Kebebasan Beragama atau Berkeyakinan Seberapa J auh?. Yogyakarta: Kanisius;
McConnell, Garvey dan Berg. 2006. Religion and The Constitution, $2^{\text {nd }}$ Edition, New York: Aspen Publisher;

Nowak, Manfred dan Tanja Vospernik. 2010. Pembatasan-Pembatasan yang Diperbolehkan terhadap Kebebasan Beragama atau Berkeyakinan, dalam Kebebasan Beragama atau Berkeyakinan Seberapa J auh?. Yogyakarta: Kanisius;

Qurtuby, Sumanto Al. 2009. Pluralisme, Dialog, dan Peacebuilding Berbasis Agama di Indonesia, dalam Merayakan Kebebasan Beragama "Bunga Rampai Menyambut 70 tahun Djohan Effendi". Jakarta: ICRP dan Kompas;

Ravitch, Frank S. 2008. Law And Religion A Reader: Cases, Concepts, And Theory. American Case Book Series, Second Edition;

Raz, J. 1988. The Morality of Freedom. Oxford: OUP;

Scolnicov, Anat. 2011. The Right to Religious Freedom in International Law Between Group Rights and Individual Rights. New York: Routledge;

Wilson, Rebbeca dan Marry R Power. 2004. Conflict Resolution Styles among Australian Christian and Moslem. Bond University: Humanity and Social Science Papers;

Yewangoe, Andreas A. 2009. Regulasi Toleransi dan Pluralisme Agama di Indonesia, dalam Merayakan Kebebasan Beragama "Bunga Rampai Menyambut 70 tahun Djohan Effendi". Jakarta: ICRP dan Kompas; 